lovely. The forests of the coal period, when the great Sycopods were at their climax, may bave exhibited some brighter greens, with tendencies towards yellow or glaucous tints; the shells of the Amonites, in the Liassic seas, may have been colored to some extent; but the great concentrating wave of organic life in its progress towards an unknown climacteric must yield an ever-increasing glory of color and form to the surface of this planet.

The beauty of summer as we know it now, though it has never been paralleled in the past, will be as nothing to the blaze of brilliance which shall mark the summers of the future.

\section{MINOR PHONETIC ELEMENTS OF MAYA HIEROGLYPHS.}

BY HILBORNE T. CRESSON, M.D., PHILADELPHIA.

THE Maya graphic system, the earliest steps of which began as picture-writing, was the natural outcome of a desire to record knowledge made by a people who may be classed as the most in telligent and civilized of the American race. The language they used, monosyllabic and rich in homophones, is in fact quite as unique as the development attained in their graphic art in its progression from thought-writing to a certain degree of soundwriting, which has been denominated ikonomatic (D. G. Brinton; "Essays of an Americanist"), "writing not by things but the sound of the names of things." Scientific research has shown that there is less reason than formerly to doubt Landa's suggestion, and that of more recent authorities, in regard to its phoneticism, which is without doubt of a higher standard than has hitherto been supposed.

Dr. Cyrus Thomas has well said in a recent article (Science, Vol. XX., No. 505, pp. 197-201) that “. . . although we may know the chief phonetic element of each part of a compound character, we cannot interpret the whole. This will undoubtedly be true unless there are indications of the minor elements." Want of complete lexicons containing words that correspond to the archaic language of the hieratic and demotic script is also a difficulty which must be considered in the work of interpretation - yet with the almost insurmountable obstacles that exist, it may be said that progress has been made in the work. A study of archaic symbols and ideographs has been made in order to determine, if possible, how certain elements used in the Maya graphic art have been derived - in most cases, we think, from the animate and inanimate forms of nature, or from things invented by man for his necessities. In these researches we must not overlook the superstitious offices of early people in symbolizing ideas - basketry, pottery, and rock-scratchings affording many valuable hints of the changes from the nature-derived elements to the more conventionalized, used ideographically or as phonetic elements, be they chief or minor elements. The figures employed may have been in many cases mere conventionalities, but there is evidence in the work of the Maya scribes that the motives of this convention are based upon primitive realism for they were but simple-minded children of nature, keen observers of her endless variety of forms, quick to adopt the motive she suggested where it could be utilized to serve a desired purpose.

That these assertions are not the outcome of mere theory we shall give, presently, a list from which we think have been derived what we deem to be phonetic elements of the Maya glyphs. Nature is the source from which have been derived the phonetic elements used by us in endeavors to interpret the Maya glyphs, and it may be said that the results are encouraging; the ideographic suggestion and the chief phonetic element having been obtained, recourse can be made to the "minor phonetic elements" - one analysis being a check to the other.

We have progressed far enough to feel sure that the Maya graphic system is based upon picture-writing, a necessary outcome in the progression of all graphic systems, from thoughtwriting to sound-writing. The majority of the glyphs, as we find them, whether hieratic or demotic, are associated with ideographs, many of these having combined with them phonetic elements which appear as glyphs or component parts of other glyphs - be they single glyphs or component parts of compound glyphs. An excellent example of an ideo-phonetic design is that of Hun Cimil, the god of the Maya hades (see plate C, Codex Peresianus, or Codex Cortesianus, p. 16). It will be remarked by consulting this first-named Codex, de Rosny's edition, that the abdomen of this figure is composed of the day-signs of Landa, the elements composing which, according to the analyses that we have made, are phonetic. In fact, we have found that sixteen out of twenty of the Maya day-signs, and many of their variants, are phonetic. We firmly believe that they will all prove to be phonetic when future study shall have demonstrated more exact methods of analysis. Between the legs are phonetic elements and the ideo-phonetic head (of a cayman?) to the right of the knee of the figure is connected with the glyph of Cimi. Around the ankles are designs that appear in the Codices, at times, as glyphs. The majority of the components of the head, arms, ornaments of the wrists, and the implements held in the left hand also appear as phonetic elements in Maya script. It is for this reason that the term "ideo-phonetic" has been used for the drawings, as they are composites conveying ideographic suggestions - the ideograph itself being intermingled at times or composed of phonetic elements that appear, as we have said, as the .component parts of other glyphs. (See figure of Hun Cimil, pp. 53,15 , Cortesianus ; p. 14, Tro., also, ibid, 3, 29, 14, 34.) Hundreds of other examples might be quoted, but as they abound throughout the Maya graphic system this will not be necessary.

The following list will indicate the animate and inanimate forms of nature and inventions of man which, it is thought, suggested certain phonetio elements of the Maya graphic system, viz. :-

$\begin{array}{llll}\text { Sky } & \text { Animals } & \text { Head } & \text { Huts } \\ \text { Sun } & \text { Birds } & \text { Eyes } & \text { Houses } \\ \text { Wind } & \text { Fish } & \text { Nose } & \text { Idols } \\ \text { Water } & \text { Reptiles } & \text { Jaws } & \text { Implements of war } \\ \text { Lightning } & \text { Insects } & \text { Mouth } & \text { and of the chase } \\ \text { Earth } & \text { Appendages of ani- } & \text { Teeth } & \text { Clothing } \\ \text { Fire } & \text { mals, birds, in- } & \text { Ears } & \text { Ornaments } \\ & \text { sects, and crus- } & \text { Tongues } & \text { Pottery } \\ & \text { taceans, etc. } & \text { Arms } & \text { Colors } \\ & & \text { Hands } & \text { Grinding-stones,etc } \\ & & \text { Feet } & \text { Tortillas } \\ & & \text { Thighs, etc. } & \text { Maize } \\ & & \text { Honey, etc. }\end{array}$

At a future time examples will be given of analyses of the Maya glyphs, the ideographic suggestion of the glyph, if any, and the drawings which accompany them, together with minor phonetic elements being considered. To give examples in this article, already longer than intended, will be impossible. The results obtained from the list to which we have assigned certain phonetic values, and used in interpretation, are encouraging - proving to our own satisfaction that minor phonetic elements undoubtedly exist in the Maya graphic system. These minor elements have in many cases been considered as meaningless decorations, component parts of ideographs. Many of the minor elements are so combined together that they are difficult to trace. Errors and omissions of the Maya scribes at times increase these difficulties and require especial study and aptitude for such analyses.

The colors, red, yellow, and black, seem to be used in the Peresianus, with phonetic and ideographic value (see plates xxiii. and xxiv.), and are combined at times with the minor elements of the glyphs. It is probable that colors are also used with a certain ideographic and phonetic value in the other Codices. Interesting combinations are to be remarked in the connection of the consonants with the vowel sounds, Landa suggests $m a, m e, m o$, for the phonetic value of a certain glyph, and this method of assigning several phonetic values to a glyph is quite common; determinatives in many cases being used to indicate the value in tended. Where these determinatives are wanting it is necessary to try the principal phonetic element through the vowel sounds. The principal phonetic value is, however, generally given by the minor elements of the glyph.

If the system and list of phonetic values adopted by the writer in the interpretation of the Maya glyphs, be correct, it suggests a higher standard of phoneticism than can well be accorded to a people, who, though the most highly civilized of the American races, were, we are to suppose, but an Indian people. Judging 
by the testimony of the minor phonetic elements there was more method and arrangement in these than we can expect trom a Maya - Indian - scribe, and for this reason the writer is prone to condemn his own work, yet repeated trials with the phonetic list arranged by him have given such good results that he is of the opinion that with careful research some good results may accrue that will be of value to students of Maya and its paleography.

It may be added, in conclusion, that the glyph known to Maya paleographers as that of "The God with the Old Man's Face," has been analyzed - its minor elements suggesting that it is that of Hoobuil-Kanil-Bacub. The suggestion given by the minor elements is "Ho-ka-n-ba-ka." The association of this glyph with "The Bee-Keeper's Narrative" of the Troano, lends a strong probability that the interpretation is a correct one, and that a former analysis attempted was erroneous.

This article is intended to be suggestive. The writer holds himself in readiness to modify any of the statements made, if the contrary be proven, or he finds in the progress of his researches that new evidence obtained proves former suggestions to be erroneous, thus only can we diminish the field of error and enlarge that of the truth.

Mexico, Jan. 3?.

\section{PRELIMINARY NOTE ON THE DISTRIBUTION OF PLACE-} NAMES IN THE NORTHERN HIGHLANDS OF SCOTLAND.

BY JOHN GUNN, ACTING SECRETARY, ROYAL PHYSICAL SOCIETY.

Nothing, at the present day, exhibits in a stronger light the effects of the Scandinavian occupation of the Northern Highlands of Scotland than the frequent occurrence of Norse place-names. And this, it must be remembered, in spite of the fact that the invaders were never permanently able to establish their own tongue as the language of the country, except in the Orkney and Shetland Islands (which form no part of the Highlands) and perhaps in certain areas in the Hebrides. The Celts have always had a wonderful power of assimilating to themselves alien races which come among them, and although subdued and ruled over by the vikings and their posterity down to the present time, caused their conquerors to adopt their language, dress, laws, and customs. Yet the number of places named by the Norsemen and still retaining these names is very remarkable.

As to general distribution, these names are more numerous along the coasts than inland. The vikings did not care to settle far from the sea, where impassable mountains and thick forests, inhabited by a warlike and hostile people, hindered convenient access to the sea. Thus as we retire from the sea-shore the place-names assume a more and more distinctly Celtic character. But even in places where the Scandinavian nomenclature more persistently prevails it is interesting to note how only the larger areas and more striking features of the landscape bear Scandinavian names. A parish, with its streams, estates, local districts, and large farms may bear names derived from the Norse, but those of crofts, burns, pools in the rivers, boulders, etc., have, as a general rule, purely Gaelic designations, many of them, doubtless, dating from a much later period than that of the Norse occupation. In this connection it is somewhat curious to observe how few mountains bear Scandinavian designations; forming bold features in the scenery, most of them must have been well known to the vikings, whose names, if they ever named many of them, have come down to us in so very few instances.

Good examples of the facts above stated may be gleaned from the topography of the county of Caithness, as there the vikings found a surer and more permanent footing than on any other part of the mainland of Scotland. The name, Caithness, is itself compound, but was undoubtedly giren by the Scandinavians, and signifies " the headland of the Calaibh," the last-mentioned word being the name of the Celtic tribe which owned the district, and resisted, although unavailingly, the invasion and partial conquest of their ancient possessions. Caithness is divided into ten civil parishes, viz., Thurso, Olrig, Dunnet, Canisbay, Bowes, Wick, Watten, Halkirk, Latheron, and Reay. All these are of Norse origin except the two last mentioned, and all, with the exception of Halkirk, have sea-coasts. Latheron and Reay are Gaelic, and these districts, along with the western portion of Halkirk, were the places in which the aborigines were left to dwell in comparative peace. Yet here, all along the coasts, we find numerous Norse derivatives, such as Skail, Lylester, Forse (occurring also in the form Forso), Berriedale, and many others. In the western Halkirk area, which lies far from the sea, we can only remember two Norse names, viz., Glutt and Rumsdale. In the Scandinavian area, however, we discover the aboriginal element to be remarkably strong. The Gael was, and is, naturally facile in topography, and gave a name to almost every object, natural and artificial, which came under his notice in a fairly permanent form. A constant pool of water, a boulder of peculiar color or somewhat uncommon shape or size, a corner of waste land, a ditch - all were named. He frequently added a word from his own vocabulary to a Scandinavian root, using oftenest Ach (a field) or Bal (a town or farm) in this connection. Thus, we get such compound forms as Achalipster, Achkipster, in which examples we have, in conjunction, the Gaelic ach and the Scandinavian ster, both words having the same meaning, and making the names tautological.

These remarks are merely intended as an introduction to a more particular examination of a subject of particular interest and of sufficient importance to have inảuced Sir Charles Wilson, Director of the Ordnance Surrey, to request the coöperation of the Scottish Geographical Society in revising the place-names for new issues of the Survey maps. The council of the society thereupon nominated a committee to undertake the work; and this committee, under the presidency of Dr. James Burgess, C.I.E., is now engaged in an examination of all the place-names in the Highlands, and, where there is any doubt, authoritatively fixing the correct form of spelling.

\section{NOTE UPON THE ABSORPTION OF SULPHUR BY CHAR- COAL.}

BY WILLIAM P. BLAKE, SHULLSBURG, WISCONSIN.

In tearing down some heaps of pyritic zinc ores, where heaproasting to expel the sulphur from the pyrite had been attempted, a part of the wood used as fuel was found at the bottom of the heap not only carbonized, but portions of it, such as small limbs of trees, and looking like ordinary charcoal, were saturated with sulphur. The original form of the wood and its structure, its grain-rings of growth, bark, etc., seemed to be perfectly retained, but the weight and solidity of the masses at once showed that some change had taken place, and this change it was easy to prove was due to the presence of a large amount of sulphur penetrating every part.

The fragments of this sulphurized carbon are hard and brittle, and break most readily at right-angles to the length of the original tree-limbs. The color is very nearly that of ordinary charcoal, but lacks the lustrous black, having instead a grayishblack shade, and when the compound is cut or scratched with a knife, it exhibits a sub-metallic lustre. Specific gravity 1.60 .

In the May number of the American Journal of Science Professor W. G. Mixter ${ }^{1}$ describes the deportment of charcoal with the halogens, nitrogen, sulphur, and oxygen. He points out the extreme difficulty in obtaining fairly pure amorphous carbon, it so tenaciously holds such elements either occluded in its pores or in combination. His experiments were conducted upon three varieties of amorphous carbon, viz., sugar charcoal, lamp-black, and gas carbon. He found that charcoal after exposure to chlorine retains a considerable quantity at high temperatures; one experiment upon heated lamp-black showing an absorption and retention of from 14.3 to 15.5 per cent, while gas carbon, ignited in chlorine and allowed to cool in a current of dry nitrogen, failed to absorb chlorine. He concurs with other recent writers on this subject that carbon and chlorine do not unite directly, but states that chlorine does combine with carbon at high temperatures when hydrogen is present in the carbon, the hydrogen being apparently replaced by chlorine; for, while gas 1 Amer. Jour. Scl., Third Series, x|v., No 269, May, 1893, p. 263. 